\title{
The impacts of COVID-19 on the world of work in Turkey*
}

\begin{abstract}
This article explores the reaction to the pandemic in Turkey, specifically as regards its impact on workers' health, livelihoods and employment. It is clear that the pandemic, which has hit Turkey very hard, has had a disproportionate impact on working people and members of the union. The government has shortened the service record required to qualify for short-time working allowance, and also imposed a ban on lay-offs, but these are far from complete solutions. Meanwhile, its relief package - the 'Economic Stability Shield' - predominantly consists of credit lines and debt relief and is also the second lowest in the G20. Times are uncertain for all workers, particularly unregistered ones, as well as for poor families in terms of meeting basic needs now and during the next period of the pandemic, on top of the employment and unemployment crisis which has already been going on since August 2018. The government has decided not to take the advice of trade unions and professional organisations, but DiSK continues to raise its voice as regards maintaining the social order both now and in the crucial post-pandemic period.
\end{abstract}

Keywords: COVID-19, trade unions, Turkey, employment protection, relief package, job loss, recovery programme

\section{Introduction}

Turkey is among the countries which have been most badly affected by the COVID-19 pandemic. With more than 160,000 confirmed positive cases by the end of May 2020, it ranks ninth while, in terms of the number of deaths (exceeding 4,500 ), it is fifteenth. The first COVID-19 case was detected in Turkey on 10 March 2020 while the first death occurred on 17 March (World Health Organisation 2020).

After the outbreak of the pandemic in Turkey, various measures were put on the agenda. The government did not approve a general quarantine and isolation proposal; instead, partial quarantine and isolation measures were implemented. First of all, schools and kindergartens were closed down. Then, places where people gather together (shopping malls, restaurants, cafes, etc.) were shut down. Citizens over 65 and under 20 are prohibited from going out on the streets, and travel restrictions have been imposed on those living in large cities. Furthermore, a curfew has occasionally been imposed, usually on weekends and public holidays.

* This article also benefits from the contributions of Aziz Çelik, Deniz Beyazbulut, Kıvanç Eliaçık and Zeynep Kandaz, for whose assistance the author is grateful. 


\section{The effect of the pandemic on workers' health}

The demands raised by the trade unions and DISK to close the economy other than for essential and compulsory work in the first place, and then stopping all other work for at least fifteen days, were not met. Millions of workers have continued to go to work using public transport. In fact, special regulations have been applied for workers to work during even the periods of curfew, with workers having been compelled to go to work. This situation has reflected badly on workers' health, as has also been shown in the research conducted by the DISK Research Centre (DISKAR). DISK-AR has sought to measure the effects of the pandemic on DISK members workers by undertaking and publishing the results of a succession of studies (DİSK-AR 2020a, 2020b, 2020d).

According to DISK-AR, the share of total COVID-19 positive cases in Turkey's population is 1.3 per 1,000 , while the ratio of cases among DİSK members to surveyed workers is 4.1 per 1,000. On 27 April 2020, the ratio of positive cases of COVID-19 among DISK members was found to be 3.2 times the rate in the general population (DİSK-AR 2020d).

\section{Legal, economic and social precautions against COVID-19}

Turkey has been experiencing the COVID-19 pandemic while having to deal with the ongoing effects of the economic crisis which has been in place since August 2018. Following the outbreak of the pandemic, the government produced a series of regulations related to the economy and labour. However, it must be noted that these regulations are very inadequate and highly limited. In particular, it made some changes to the labour laws as a result of the pandemic, the most important of which are the changes made to the Unemployment Insurance Law and the Labour Law. In March 2020, the periods before an employee is able to benefit from short-time working allowance - a 600-day record of unemployment insurance premiums being paid on behalf of the employee over the last three years; and continuous employment over the last 120 days - were reduced during the pandemic to, respectively, 450 and 60 days.

With the Law on the Economic and Social Risks of COVID-19 No. 7244, adopted on 17 April 2020, a three-month ban on lay-offs was imposed. However, despite this ban, employers were given the opportunity to make workers take unpaid leave. The Law does set out that some level of monetary support (i.e. of 39 TL per day; $€ 5.15$ ) should be provided to workers on unpaid leave.

The lay-off ban means that employment is protected, but only on paper, and support from the Unemployment Insurance Fund for those who have lost their jobs is provided only for three months. Consequently, the more widely-applicable support is the short-time work allowance, which provides a level of support to workers who have lost their jobs as well as income for the time in which they can not work. In the latter case, the employment contract does not end.

In March 2020, the government announced a package called the 'Economic Stability Shield' against the effects of COVID-19. Initially, the package was set at $100 \mathrm{bn}$ TL (approximately $€ 13.25 \mathrm{bn}$ ) but it now stands at more than $285 \mathrm{bn}$ TL 
(€38bn). However, it may be seen that such a value is somewhat over-inflated since it includes credit facilities and debt relief which dominate the overall size of the package. Consequently, the amount of cash for citizens and employees that it contains is very low.

Furthermore, the overall value of the package announced by the government is, in terms of the relationship with GDP, the second lowest among G20 countries (see Figure 1).

Figure 1 - Announced fiscal measures in G20 economies as a percentage of GDP

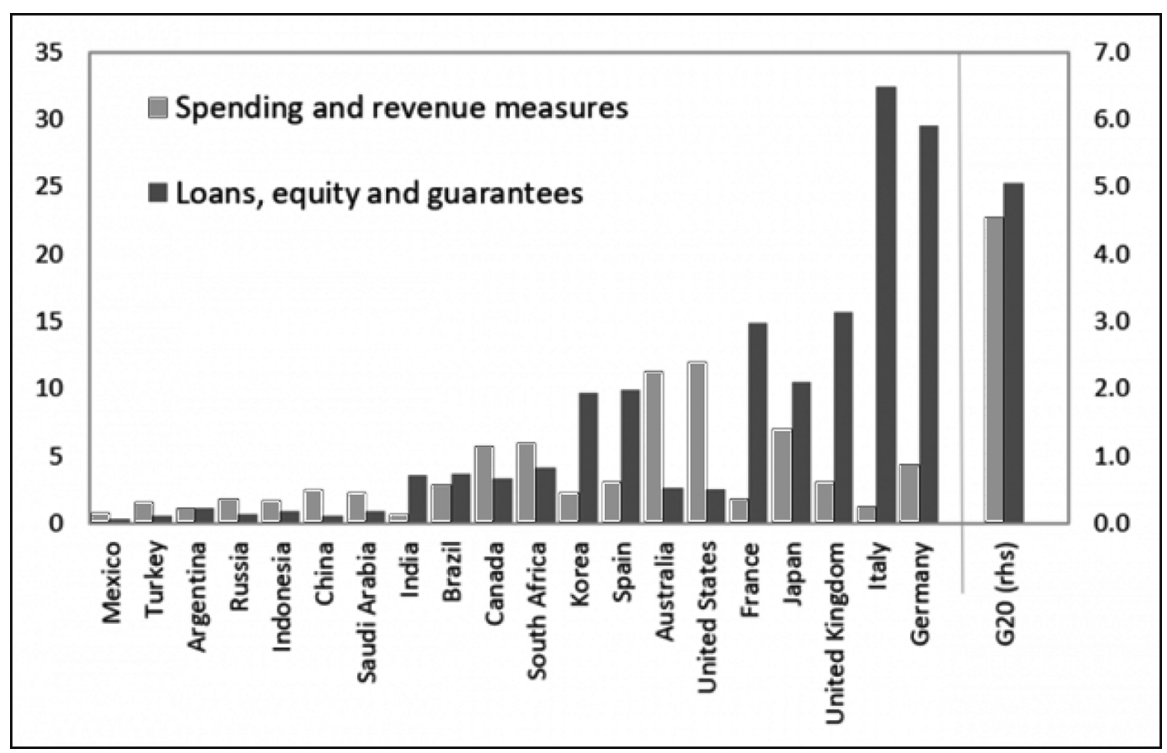

Source: Battersby et al. (2020)

Indeed, according to the research set out in Table 1, some 96 per cent of the package is represented by debt relief and credit facilities, with just four per cent consisting of cash support. As a result of the effects of the pandemic, $4.5 \mathrm{~m}$ people have received a total of 6 bn TL $(€ 795 \mathrm{~m})$ from the Unemployment Insurance Fund, while $5.5 \mathrm{bn}$ TL (€730m) has been provided to $5.5 \mathrm{~m}$ poor families on the basis of a cash support grant of 1,000 TL (€132) for each. Total cash support amounts, therefore, to just 11.5bn TL.

At the same time, the total amount of tax, home and insurance debt postponements included in the Economic Stability Shield exceeds 270 bn TL (Çelik 2020b).

Transfers from the Unemployment Insurance Fund to workers and unemployed were also far lower than expected. The $6 \mathrm{bn}$ TL provided to $4.5 \mathrm{~m}$ workers indicates an average pay-out of 1,333 TL ( $€ 176)$; while the average short-time work allowance per worker is 1,591 TL (€199) and unpaid leave allowance per worker is $502 \mathrm{TL}$ (€66). There is no chance of saying that Unemployment Insurance Fund resources 
have been used effectively considering that the Fund contains some 130bn TL $(€ 17 \mathrm{bn})$. In view of the government having invested Unemployment Insurance Fund resources in domestic government bonds, it is reluctant to cash out the Fund's resources because of concerns over monetary expansion and inflation (Çelik 2020a).

The situation faced by unregistered workers and the poor is particularly uncertain. If the average number of family members is taken as four people, it is evident that the 1,000 TL in Cash Support provides a grant of just $250 \mathrm{TL}(€ 33)$ per person during a pandemic period which has now lasted for more than two months.

Table 1 - Economic measures taken against COVID-19 in Turkey via the 'Economic Stability Shield'

\begin{tabular}{|c|c|c|c|c|}
\hline Support / credit / debt type & Scope & $\begin{array}{l}\text { Amount } \\
\text { (TL, bn) }\end{array}$ & Financing type & $\begin{array}{c}\text { Share } \\
\text { (per cent) }\end{array}$ \\
\hline 1,000 TL Cash Support & $\begin{array}{l}5.5 \mathrm{~m} \\
\text { families }\end{array}$ & 5.5 & Cash support & $2 \%$ \\
\hline $\begin{array}{l}\text { Short Work, Cash Wages and } \\
\text { Unemployment Allowance }\end{array}$ & $4.5 \mathrm{~m}$ people & 6 & $\begin{array}{l}\text { Unemployment } \\
\text { benefit }\end{array}$ & $2 \%$ \\
\hline SSK and Bağ-Kur Debt Relief & & 66 & Debt relief & $23 \%$ \\
\hline Individual Needs Support & $6 \mathrm{~m}$ people & 37 & Credit/debt & $13 \%$ \\
\hline Artisan Support Finance & $\begin{array}{c}1.1 \mathrm{~m} \\
\text { artisans }\end{array}$ & 25 & Credit/debt & $9 \%$ \\
\hline Business Continuation Finance & $\begin{array}{l}181,000 \\
\text { enterprises }\end{array}$ & 145.6 & Credit/debt & $51 \%$ \\
\hline Total Package & & 285.1 & & $100 \%$ \\
\hline $\begin{array}{l}\text { Total Cash Support (Social Aid + } \\
\text { Unemployment benefit) }\end{array}$ & & 11.5 & Cash Support & $4 \%$ \\
\hline $\begin{array}{l}\text { Total Credit and Debt Support/ } \\
\text { Relief }\end{array}$ & & 273.6 & Credit and Debt & $96 \%$ \\
\hline
\end{tabular}

Source: Çelik (2020b)

Job and income loss as a result of the pandemic in Turkey

Regular data has not yet been published, but some limited data which has been shared by the Ministry of Treasury and Finance and the Ministry of Family, Labour and Social Services (MCHFH) reveal that the pandemic has caused a huge loss of income. As reported by MCHFH and IŞKUR (Turkish Employment Agency), the more than 4.5 million insured workers who have applied for ISSKUR benefit payments due to unemployment and income loss comes out of a total of $14.2 \mathrm{~m}$ workers registered with the agency.

This number, however, does not include insured workers who are registered but cannot apply for payments from IŞKUR because they fail to meet the qualification criteria; and also those who are unregistered and have lost their source of income 
through unemployment. Approximately $4.8 \mathrm{~m}$ people work in the informal non-agricultural sector in Turkey. Likewise, about $2.8 \mathrm{~m}$ self-employed people (artisans and small entrepreneurs) are not included in this scope. As reported by Aziz Çelik, a faculty member at the Faculty of Economics and Administrative Sciences of Kocaeli University, it may be that job and income loss as a result of the pandemic have affected more than seven million employees - i.e. approximately one-third of the 22.6m non-agricultural workforce (Çelik 2020b).

Field studies confirm the difficulties of this situation. For instance, Prof. Dr. Veysel Bozkurt from the Faculty of Economics of Istanbul University stated in a study conducted using social media channels and covering urban, educated, middle and upper classes, that 47 per cent of paid employees in the private sector noted that they were concerned about meeting their basic needs for the next two months (Bozkurt 2020).

It can be seen that the effects of the epidemic are larger in the big cities. According to a survey conducted by CHP Istanbul, some 66.2 per cent of the total working population in the city has experienced a decrease in income, of either a greater or lesser amount, while one in every four employees in Istanbul are now unemployed (CHP 2020). Likewise, according to a study conducted by DISK member union Birleşik Metal-İş, 75 per cent of metalworkers stated that their income had decreased due to the COVID-19 epidemic (BİSAM 2020).

\section{Possible impact of COVID-19 on the labour market in Turkey}

There was an economic crisis in Turkey even before the pandemic. Data for February, which did not yet include the impact of the pandemic, revealed an extremely negative situation in the Turkish labour market. The economic crisis that began in August 2018 has led to a drastic decline in employment and a consequent explosion of unemployment in Turkey. The number of employed people, which reached 29.3m in August 2018, had decreased to 26.75m in February 2020 - i.e. a loss of employment during this period of more than $2.5 \mathrm{~m}$ jobs.

This has resulted in a colossal increase in the number of unemployed people. The number of unemployed people on a narrow definition was announced as $4.2 \mathrm{~m}$ in February 2020, while the number of unemployed people on a broad definition was calculated by DISK-AR as $8.5 \mathrm{~m}$ in that same month (DISK-AR 2020e). Broad unemployment, as calculated by the union, stood at $7.6 \mathrm{~m}$ in February 2019. Urban young female unemployment exceeded 40 per cent while the rate of real unemployment stood at 24.5 per cent. Youth unemployment was at a peak with, as across the whole population, one out of every four young people unemployed.

Narrowly-defined unemployment is actually decreasing, but one of the reasons for the increase in unemployment on the broad definition is the remarkable increase in the number of people who are not looking for a job despite being ready to work. The number of unemployed people who have lost hope of work as a result of their long-term unemployment during the crisis has increased by more than 75 per cent in the last year, now reaching $1.11 \mathrm{~m}$ and representing a rise from 621,000 in February 2019. 
Detailed data have not yet been announced, but it is possible to estimate job loss and the shrinkage in employment due to COVID-19. According to DISK-AR's research, the effects of COVID-19 in the first three months (March-May) is that there will be 7-8 million job losses. Thus, the early period of COVID-19 could see unemployment on the narrow definition reaching $12 \mathrm{~m}$ people while, on the broad definition it could rise to some 15-16m (DISK-AR 2020e).

\section{DiSK's routemap out of the COVID-19 pandemic}

As soon as the pandemic emerged, DİSK conveyed its views to the government on the measures to be taken and the policies which should be followed. Together with other labour and professional organisations, common policies were developed and presented to the public. These views on how the worst effects of the crisis could be ameliorated are set out briefly as follows:

- we demanded that the pandemic process be conducted in a transparent and participatory way. We suggested that the health dimensions of COVID-19 should be handled together with the professional healthcare organisations, and the economic and social dimensions with the unions. It is a great pity that the government has chosen to run the process alone

- we demanded the banning of lay-offs. This request was implemented quite late and is incomplete, with lay-offs only being banned on 17 April and then only partially

- we advocated the stopping of all non-mandatory and non-urgent work and paid leave for workers

- we advocated the implementation of a short-time working allowance for insured workers in the private sector against the loss of income during the period of the pandemic; and that all workers should benefit from this without preconditions

- we brought up the issue of regular social security and family insurance for unregistered workers. We advocated that the government should guarantee the livelihoods of citizens affected by the pandemic and who are unable to have adequate social security protection

- the COVID-19 pandemic increases women's domestic workload while deepening the sexist social division of labour. It also raises violence against women. For this reason, we argued that measures should be taken within the scope of gender policies

- we raised the demand for retirement pensions to be raised to the level of the lowest minimum wage

- we advocated delaying household water, electricity, natural gas and telecommunications bills, without applying interest, and excluding VAT in these services

- we advocated postponing credit card debt and considering worker loans

- we brought up the question of an effective wealth tax on the one hand and the use of Central Bank funds on the other to create the resources required to emerge from the pandemic.

To our regret, although we expressed these demands in conjunction with many labour and professional organisations, the government did not take the steps we demanded. Furthermore, it has not produced effective social policies against the pan- 
demic, and has withdrawn from fulfilling the requirement of the principle of the social state as set out in the Constitution.

How right we were in our views is being proven on a day-to-day basis. At this point - early June - a new era in the battle against the pandemic is on the agenda in which a partial softening of the measures and the re-mobilisation of social life will be in question. With this in mind, DİSK has published a routemap plotting a way out of the crisis and including a series of urgent measures to maintain the social order during the struggle against COVID-19 and for the rebuilding of the economy in the post COVID-19 period (DİSK 2020).

\section{References}

Statements of Zehra Zümrüt Selçuk, Minister of Family and Social Services: https:// www.trthaber.com/haber/gundem/bakan-selcuk-ucretsiz-izin-destegi-odemeleri-y arin-basliyor-482641.html [last accessed 10 May 2020].

Battersby, B, W. Raphael Lam and Elif Ture (2020) 'Tracking The \$9 Trillion Global Fiscal Support To Fight COVID-19', IMF Blog 20 May 2020, available at: https:/ /blogs.imf.org/2020/05/20/tracking-the-9-trillion-global-fiscal-support-to-fight-c ovid-19 [last accessed 28 May 2020].

BİSAM (2020) COVID-19 Sürecinde Gelir Kaybı ve Borçluluk Araştırması (Survey on debt and the loss of income during COVID-19) available at: http://www.birlesikmetalis.org/index.php/tr/guncel/basin-aciklamasi/1486-bisam05 [last accessed 29 May 2020].

Bozkurt, Veysel (2020) 'Pandemi Döneminde Çalışma' ('Employment in a time of pandemic') in Dilek Demirbaş, Veysel Bozkurt and Sayım Yorğun (Eds.) Kovid-19 Salgının Ekonomik, Sosyal ve Siyasal Etkileri ve Türkiye’ye Yönelik Öneriler (Economic, Social and Political Implications of the COVID-19 Outbreak and Suggestions for Turkey), İstanbul Üniversitesi İktisat Fakültesi, yayımlanmamış araştırma (unpublished research).

CHP (2020) Report on Work Life Outlook in Istanbul available at: https://www.chpistanbul.org.tr/Haberler/11/istanbulda-her-4-calisandan-1i-issiz-kaldi-86148.asp $\mathrm{x}$.

Çelik, Aziz (2020a) 'İşsizlik Sigortası Fonu'nda gerçekten para yok mu?' ('Is there really no money in the Unemployment Insurance Fund?') BirGün 20 April 2020, available at: https://www.birgun.net/haber/issizlik-sigortasi-fonu-nda-gercekten-p ara-yok-mu-297328.

Çelik, Aziz (2020b) 'İş ve gelir kaybı devasa, gelir desteği devede kulak!' ('Huge loss of jobs and income, but income support a drop in the bucket') BirGün, 25 May 2020, available at: https://www.birgun.net/haber/is-ve-gelir-kaybi-devasa-ge lir-destegi-devede-kulak-302161.

DİSK (2020) DISK's Routemap During and After COVID-19, http://disk.org.tr/2020/ 05/covid-19-doneminde-ve-sonrasinda-diskin-calisma-yasami-yol-haritasi/. 
DISK-AR (2020a) COVID-19 DISK Report 1 http://disk.org.tr/2020/04/disk-uyeleriarasinda-salginin-etkileri-covid-19-disk-raporu/.

DISK-AR (2020b) COVID-19 DISK Report 2 http://disk.org.tr/2020/04/covid-19-dis k-raporunun-ikincisi-yayinlandi/.

DISK-AR (2020c) COVID Cases Among Workers http://disk.org.tr/2020/04/rate-of-c ovid-19-cases-among-workers-at-least-3-times-higher-than-average/.

DISK-AR (2020d) COVID-19 DISK Report 3 http://disk.org.tr/2020/04/covid-19-dis k-raporunun-ucuncusu-yayinlandi/.

DISK-AR (2020e) Employment and Unemployment Outlook Report May 2020, http:/ /disk.org.tr/2020/05/mayis-2020-issizlik-ve-istihdam-raporu/.

TURKSTAT (2020) Household Labour Force Survey February 2020.

World Health Organization Database available at: https://covid19.who.int [last accessed 28 May 2020]. 